\title{
Penerapan Model Group Investigation Berbantuan Media Puzzle untuk Meningkatkan Hasil Belajar Siswa Sekolah Dasar
}

\author{
Siti Khoenun Nisa ${ }^{1]}$, Ika Ari Pratiwi ${ }^{2]}$, Erik Aditia Ismaya ${ }^{3]}$ \\ Universitas Muria Kudus \\ E-mail: ${ }^{1]}$ khoirunn588@ gmail.com

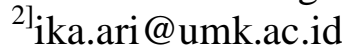 \\ ${ }^{3]}$ erik.aditia@umk.ac.id
}

\begin{abstract}
Abstrak
Dilakukannya penelitian ini meliputi latar belakang berdasarkan hasil belajar siswa rendah. Tujuan penelitian ini mendeskripsikan peningkatan hasil belajar siswa kelas $\mathrm{V}$ SD 5 Bae menggunakan Model Pembelajaran Group Investigation dengan berbantuan media puzzle pada Tema 6 Panas dan Perpindahannya muatan PPKn dan IPS tahun ajaran 2019/2020. Metode penelitian yang digunakan dalam penelitian ini yaitu penelitian tindakan kelas (PTK), dilaksanakan dengan dua siklus, setiap siklus terdiri dari empat tahap yakni perencanaan, pelaksanaan, observasi dan refleksi. Lokasi penelitian di SD 5 Bae yang beralamat di desa Krajan Kecamatan Bae Kabupaten Kudus. Subjek penelitian yaitu siswa kelas V SD 5 Bae semester II tahun ajaran 2019/2020 yang berjumlah 21 siswa terdiri dari 5 perempuan dan 16 laki-laki. Sumber data penelitian yaitu guru dan siswa. Teknik pengumpulan data meliputi teknik wawancara, observasi, tes, dan dokumentasi. Validitas data yang digunakan yaitu Expert Judgement dengan menggunakan teknik analisis data kualitatif dan kuantitatif. Hasil penelitian siklus I memperoleh rata-rata nilai klasikal 71 dengan keterangan siswa belum tuntas 10 siswa persentase $48 \%$ dan belum tuntas 11 siswa dengan persentase 52\%. Pada siklus I memperoleh nilai teringgi 87 dan nilai terendah 40 , meningkat pada siklus II memperoleh rata-rata nilai klasikal 75 dengan keterangan siswa yang tuntas 16 siswa persentase $76 \%$ dan belum tuntas 5 siswa dengan persentase 24\%. Pada siklus II memperoleh nilai tertinggi 93 dan nilai terendah 50 . Berdasarkan penelitian tindakan kelas dapat disimpulkan bahwa menggunakan model Group Investigation berbantuan media Puzzle dapat meningkatkan hasil belajar siswa kelas V SD 5 Bae.
\end{abstract}

Kata Kunci: Media Puzzle, Group Investigation, Tema 6

\section{The Application of a Group Investigation Model Assisted by Puzzle Media to Improve Learning Outcomes of Elemantary School Students}

\begin{abstract}
Conducting this research includes a background based on low student learning outcomes. The purpose of this study is to describe the increase in learning outcomes of students in class VSD 5 Bae using the Group Investigation Learning Model with media puzzle assisted on the theme of 6 Hot and the Displacement of civic and social
\end{abstract}


studies content in the 2019/2020 school year. The research method used in this study is classroom action research (CAR), carried out in two cycles, each cycle consisting of four stages namely planning, implementing, observing and reflecting. The research location is SD 5 Bae which is located in Krajan Village, Bae Subdistrict, Kudus Regency. The subjects of the study were the fifth grade students of Bae Elementary School in the second semester of the 2019/2020 school year, totaling 21 students consisting of 5 women and 16 men. Research data sources are teachers and students. Data collection techniques include interview, observation, test, and documentation techniques. The validity of the data used is Expert Judgment using qualitative and quantitative data analysis techniques. The results of the first cycle of research obtained an average classical value of 71 with the statement of students not yet completed 10 students the percentage of $48 \%$ and 11 students not yet completed with a percentage of 52\%. In cycle I obtained the highest value of 87 and the lowest value of 40 , increased in cycle II obtained an average of 75 classical grades with the description of students who completed 16 students as a percentage of $76 \%$ and unfinished 5 students with a percentage of 24\%. In cycle II, the highest score is 93 and the lowest value is 50. Based on classroom action research it can be concluded that using the Group Investigation model assisted by Puzzle media can improve student learning outcomes in grade V SD 5 Bae.

Keywords: Learning Outcomes, Group Investigation, Puzzle.

\section{PENDAHULUAN}

Pendidikan mempunyai peran penting dalam menentukan sumber daya manusia, pendidikan di Indonesia juga mempunyai tujuan yang harus dicapai. Berdasarkan dengan peraturan Menteri Pendidikan dan Kebudayaan Republik Indonesia Nomor 57 Tahun 2014 tentang tujuan Kurikulum 2013 Sekolah Dasar atau Madrasah Ibtidaiyyah yaitu "Kurikulum 2013 bertujuan untuk mempersiapkan manusia Indonesia agar memiliki kemampuan hidup sebagai pribadi dan warga ngara yang beriman, produktif, kreatif, inovatif dan efektif serta mampu berkonstribusi pada kehidupan bermasyarakat, berbangsa, bernegara dan peradaban dunia. Upaya peningkatan dan pembaharuan kualitas pendidikan pemerintah memastikan diterapkanya kurikulum yakni kurikulum 2013.

Pembelajaran tematik integratif mengajarkan kepada siswa menghubungkan pengetahuan dan pengalaman mereka sehari-hari sehingga siswa dapat menyelesaikan masalah dan memenuhi kebutuhan pengetahuan mereka. Upaya peningkatan dan pembaharuan kualitas pendidikan pemerintah memastikan diterapkanya kurikulum yakni kurikulum 2013.

Pada kurikulum 2013 seorang guru dituntut agar pembelajaran berbasis tematik integratif. Pembalajaran tematik bukan hal yang baru di dunia pendidikan pembelajaran tematik sudah di terapkan pada kurikulum KTSP. Pada kurikulum KTSP sudah diterapakan pada kelas I, II dan III SD. Kesiapan guru sangat penting karena dalam tujuan kurikulum 2013 guru harus mendorong siswa atau siswa mampu lebih baik dalam melakukan observasi,bertanya, bernalar, membuat pembelajaran yang lebih menarik dan seru dan mengkomunikasikan serta 
mempresentasikan, apa yang mereka peroleh setelah materi pemebelajaran.

Kemendikbud

menjelaskan pembelajaran tematik integratif merupakan pendekatan yang mengintegrasikan berbagai kompetensi dari berbagai mata pelajaran ke dalam berbagai tema. Pengintegrasian dilakukan dalam 2 hal integrasi sikap, keterampilan, dan pengetahuan dalam proses pembelajaran dan integrasi berbagai konsep dasar yang berkaitan. Pembelajaran tematik integratif mengajarkan kepada siswa menghubungkan pengetahuan dan pengalaman meraka sehari-hari sehingga siswa dapat menyelesaikan masalah dan memenuhi kebutuhan pengetahuan mereka, yang dimiliki peserta didik bukan hanya pengetahuan, peserta didik juga harus mempunyai rasa sosial dan mempunyai rasa nasionalisme. Dengan pendidikan PPKn peserta didik mampu meningkatkan rasa nasionalisme dan rasa cinta tanah air serta bisa menghargai jasa pahlawan.

Pembelajaran PPKn merupakan salah satu mata pelajaran yang diberikan kepada semua peserta didik mulai dari sekolah dasar hingga perguruan tinggi untuk menyiapkan para sisiwa kelak sebagai warga masyarakat sekaligus sebagai warga negara yang baik. Pembelajaran PPKn pada jenjang pendidikan dasar dan menengah mengandung komitmen utama dalam pencapaian tujuan pengembangan kepribadian yang mantap dan mandiri serta rasa tanggung jawab kemasayarakatan dan kebangsaan (Zuhairah, 2015: 134). PPKn sangat penting khususnya untuk sekolah dasar untuk dapat berperilaku sesuai dengai norama-norma atau kaidah yang berlaku untuk kehidupan sehari-hari baik di lingkungan sekolah maupun di lingkungan masyarakat. Peserta didik bukan hanya didik menjadi masyarakat yang baik dan taat norma-norma yang berlaku, tetapi peserta didik juga diajarkan dengan ilmu sosial dan wawasan yang luas agar peserta didik juga mempunyai kemajuan ilmu ketika turun dimasyarakat. Melalui Pendidikan Ilmu Pengetahuan Sosial peserta didik memperoleh pengetahuan dan wawasan yang luas mengenai konsep-konsep dasar Ilmu Pendidikan Sosial.

Pembelajaran IPS di Sekolah Dasar dapat mendidik dan memberikan bekal dan kemampuan dasar kepada siswa untuk mengembangkan diri sesuai bakat, minat, kemampuan, dan lingkungan serta sebagai bekal siswa untuk melanjutkan pendidikan ke jenjang yang lebih tinggi. Gunawan (2011) menyatakan bahwa tujuan pendidikan IPS adalah membina anak didik menjadi warga negara yang baik, yang memiliki pengetahuan, dan kepedulian sosial. IPS tidak hanya memberikan ilmu pengetahuan, tetapi berorientasi pada pengembangan ketereampilan berfikir kritis, sikap, dan kecakapan-kecakapan dasar siswa yang berpijak pada kenyataan kehidupan sosial kemasyarakatan sehari-hari dan memenuhi kebutuhan bagi kehidupan sosial siswa di masyarakat. Meskipun memiliki peran yang penting, namun dalam proses pembelajaran PPKn dan pembelajaran IPS masih menemui kendala dan kelemahan.

Implementasi Kurikulum 2013 di SD 5 Bae sudah diterapkan pembelajaran dengan pendekatan tematik terpadu dari kelas satu sampai kelas enam di antaranya pada mata pelajaran IPS dan PPKn.

Berdasarkan hasil observasi yang dilaksanakan di SD 5 Bae Kudus, pada hari jum'at tanggal 19 Juli 2019, 
diperoleh informasi bahwa siswa belum sepenuhnya terlibat secara langsung saat pembelajaran, seperti halnya pada kelas V bahwa kegiatan pembelajaran masih di dominasi oleh guru dengan menggunakan, kurangnya penggunaan model-model yang memancing aktivitas siswa, guru tidak menggunakan media pembelajaran. Bedasarkan pengamatan peneliti banyak siswa yang tidak mendengarkan penjelasan dari guru kerana pembelajaran yang terlalu monoton.

Berdasarkan hasil wawancara guru dan siswa Kelas V SD 5 Bae, diketahui bahwa guru kelas $\mathrm{V}$ mengalami kendala karena pada mata pelajaran PPKn dan IPS terlalu banyak materi sehingga membuat sisiwa sulit memahami dan menghafal materi sehingga membuat hasil belajar siswa rendah.

Berdasarkan hasil prasiklus yang dilakukan di SD 5 Bae dari 21 siswa hanya $9(42,8 \%)$ siswa yang tuntas, dan $12(57.1 \%)$ yang belum tuntas. Untuk muatan PPKn dari 21 siswa hanya $7(33,3 \%)$ siswa yang tuntas, dan $14(66,6 \%)$ yang belum tuntas. Pada saat observasi pasiklus ditemukan siswa yang tidak memperhatikan guru saat menerangkan materi karena siswa bosan dengan materi yang banyak dan banyak siswa yang belum memahami materi tersebut.

Berdasarkan adanya permasalahan tersebut perlu adanya upaya untuk meningkatkan hasil belajar siswa agar memiliki hasil yang bagus dan pemahan PPKn dan IPS yang lebih baik. Menurut para ahli Snelbeker dalam Rusmono ( 2012: 8) menyatakan bahwa hasil belajar merupakan perubahan atau kemampuan baru yang diperoleh siswa setelah melakukan perbuatan belajar, karena belajar pada dasarnya adalah perilaku sesorang berubah sebagai akibat dari pengalaman. Hamalik dalam Kunandar (2013: 62) menjelaskan bahwa hasil belajar adalah pola-pola perbuatan , nilai-nilai, pengertian-pengertian dan sikap-sikap serta kemapuan peserta didik. Hasil belajar adalah kompetensi atau kemampuan teretentu baik kognitif, afektif maupun psikomotorik yang di capai atau dikuasi peserta didik setelah mengikuti proses belajar mengajar. Untuk meningkatkan hasil belajar siswa dalam mata pelajaran PPKn dan IPS, peneliti melakukan diskusi deengan guru kelas V di SD 5 Bae.

Berdasarkan hasil diskusi dan kesepakatan dengan guru kelas $\mathrm{V}$ dan peneliti model yang dapat mengatasi masalah tersebut yaitu dengan menggunakan model Group Investigation dapat mengatasi masalah tersebut dengan pemahaman materi lebih mudah, pembelajaran yang kreatif dan inovatif dan menyenangkan bagi anak-anak, sehingga meningkatkan hasil belajar siswa dalam pembelajaran tematik IPS dan PPKn di kelas V SD 5 Bae.

Model Group Investigation
adalah suatu model pembelajarn kooperatif, metode yang menggunakan cara berkelompok (Group) dan memecahkan sebuah masalah (Investigation). Shoimin (2014: 80) Group Investigation adalah suatu pembelajaran yang lebih menekankan pada pilihan dna kontrol siswa dari pada menerapkan teknik-teknik pengajaran di ruang kelas. Suyatno dalam Tanireja, et.al (2009: 56) sintaks model pembelajaran kooperatif tipe Group Investigation (GI), yaitu: 1) mengidentifikasi topik dan mengorganisir siswa ke dalam kelompok; 2) merencanakan tugastugas belajar; 3) melaksanakan 
investigasi/ penyelidikan; 4) menyiapkan laporan akhir; 5) mempresentasikan laporan akhir; dan 6) mengevaluasi pemahaman siswa.

Pemilihan model pembelajaran Group Investigation sebagai upaya perbaikan serta peningkatan kualitas pembelajaran pada siswa kelas V SD 5 Bae senada dengan riset Erlisnawati dan Marhadi (2014), Muhajir dan Rukman (2018), Ariyani et al (2019), Ermina dan Zamifa (2013), Febriyani dan Raudhah (2015). Berdasarkan penelitian yang relevan diatas dapat di simpulkan bahwa dengan menggunakan model Group Investigations dapat meningkatkan keterampilan guru, aktivitas siswa dan meningkan hasil belajar siswa. Media Puzzle juga dapat meningkatkan hasil belajar siswa.Selanjutnya peneliti akan melakukan penelitian pada kelas $\mathrm{V}$ di SD 5 Bae dan pada penelitian kali ini dapat menjadi refrensi atau pelengkap bagi peneliti-peneliti lainnya. Adapun perbedaan penelitian yang dilakukan dengan riset tersebut diatas yaitu pada pemilihan media, subyek penelitian, mata pelajaran, serta jenis penelitian.

Berdasrkan diskusi dan kesepakatan dengan guru kelas $\mathrm{V}$ mengenai media yang akan membantu mempermudah siswa dalam belajar yaitu dengan menggunakan media puzzle. Media puzzle merupakan salah satu media yang dapat mempermudah siswanya untuk dapat memahami materi dan dapat membantu guru dalam pembelajaran. Menurut para ahli Santrianawati (2018: 67) menyatakan bahwa media Puzzle merupakan sebuah media alternatif yang dapat di terapakan dalam meningkatkan hasil belajar siswa, puzzle bersifat bongkar pasang. Rumakhit (2017) menyatakan bahwa Media puzzle merupakan media pembelajaran yang sifatnya memberikan rasa nyaman berfikir melalui permainan dimaksudkan agar dalam kegiatan pembelajaran lebih menarik dan siswa lebih tertarik, Media puzzle bermanfaat untuk meningkatkan kreatifitas siswa, keaktifan siswa, dan menghidupkan rasa ingin tahu siswa, sehingga pengetahu an siswa akan bertambah.

Dengan adanya model pembelajaran group investigation berbantuan media puzzle dapat meningkatkan hasil belajar siswa terhadap pembelajaran. Sehingga siswa dapat menjadi acuan pembelajran yang kreatif inovatif dan menyenangkan bagi siswa, karena itu perlu diterapkan di SD 5 Bae.

Mendeskripsikan peningkatan hasil belajar siswa kelas V SD 5 Bae menggunakan Model Pembelajaran Group Investigation dengan berbantuan media puzzle pada Tema 6 Panas dan Perpindahannya muatan PPKn dan IPS tahun ajaran 2019/2020.

\section{METODE}

Metode penelitian yang digunakan dalam penelitian ini adalah penelitian tindakan kelas (PTK). Subjek penelitian yaitu siswa kelas V SD 5 Bae semester II tahun ajaran 2019/2020 yang berjumlah 21 siswa yang terdiri dari 5 perempuan dan 16 laki-laki. Sumber data penelitian yaitu guru dan siswa dilaksanakan dengan dua siklus, setiap siklus terdiri dari empat tahap yakni perencanaan, pelaksanaan, observasi dan refleksi. Bagan Penelitinan Tindakan Kelas (PTK) Arikunto (2011: 17). 


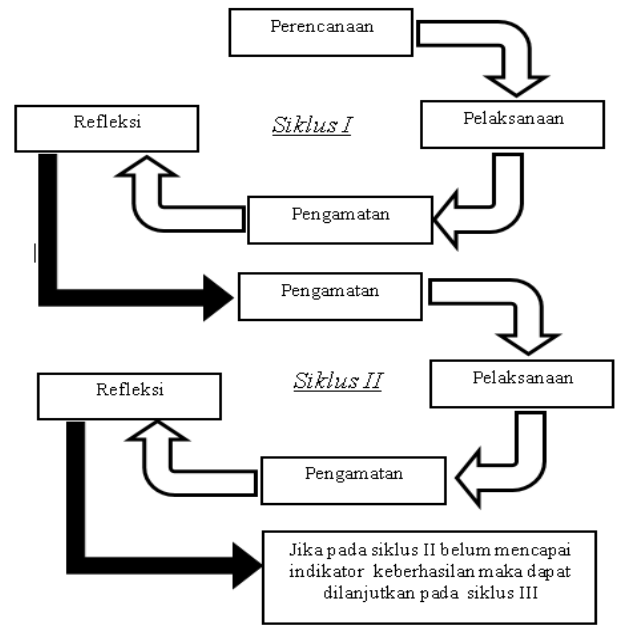

Gambar 1. Bagan penelitian Tindakan Kelas (PTK)

Sumber data penelitian yaitu guru dan siswa. Teknik pengumpulan data meliputi teknik wawancara, observasi, tes, dan dokumentasi. Validitas data yang digunakan yaitu Expert Judgement dengan menggunakan teknik analisis data kualitatif dan kuantitatif.

\section{HASIL DAN PEMBAHASAN}

Penelitian tindakan kelas dilakukan dengan persetujuan guru kelas V SD 5 Bae dengan waktu pelaksanaan siklus I pada tanggal 7 dan 9 Januari 2020 dan siklus II dilaksanakan pada tanggal 14 dan 16 Januari 2020.

\section{Siklus I}

\section{a. Perencanaan}

Perencaan yaitu kegiatan yang dimulai dengan merencanakan ide peneliti yang merupakan hasil tindak lanjut dari observasi dikelas yang bertujuan untuk menemukan faktorfaktor penghamabat yang menyebabkan hasil pemebelajaran yang masih rendah. Pada permasalahan yang muncul, peneliti menggunakkan model Group Investigation berbantuan media puzzle untuk meningkatkan hasil belajar siswa. Tahap perencaan siklus I hal yang dilakukan oleh peneliti, sebelum peneliti melakukan penelitian tindakan kela adapun kegiatan yang dilakukan dalam tahap perencanaan pada siklus I antara lain: Membuat silabus, Membuat Rencana Pelaksanaan Pembelajaran (RPP), Membuat Lembar Kerja Siswa (LKS), Menyiapkan media, Membuat soal evaluasi untuk siklus I, Menentukan instrumen, Membuat pedoman observasi mengenai hasil belajar siswa, Peneliti merencanakan pembentukan kelompok heterogen

\section{b. Pelaksanaan}

Tahap pelaksanaan tindakan siklus I peneliti melaksanakan penelitian dan sekaligus menjadi guru pada siklus I pertemuan I dan Pertemuan II dikelas V SD 5 Bae, pada pelaksanaan penelitian, peneliti menggunakan pedoman RPP yang sudah dibuat sesuai dengan langkah model Group Investgation berbantuan media Puzzle. Tahap kedua yakni pelaksanaan. Dalam penelitian dilaksanakan dengangan menerapkan model Group Investigation berbantuan media Puzzle untuk meningkatkan hasil belajar siswa pada tema 6 di SD 5 Bae. Pada pelaksanaan tindakan kelas pada siklus I pertemuan I yaitu pada hari Selasa, 07 Januari 2020, dan siklus I pertemuan II pada hari Kamis, 09 Januari 2020

Penelitian siklus I pertemuan I dilaksanakan hari selasa 7 Januari 2020 pukul 09.00 - 12.30 WIB dengan alokasi waktu 4 x 35 menit materinya hak di sekolah dan interaksi manusia dengan lingkungan alam. Pada tahap ini memiliki tiga tahapan yaitu kegiatan awal, kegiatan inti dan kegiatan penutup. 
Kegiatan awal merupakan kegiatan guru mengkondisikan, berdo'a bersama dan mengecek kehadiran siswa, guru bersama siswa menyanyikan lagu nasional seperti "Indonesia raya".guru melakukan apersepsi sebelum masuk ke pembelajaran. Masuk selanjutnya yakni kegiatan inti dalam kegiatan inti guru menerapkan langkah-langkah model Group Investigation, adapun tahapanya ada 6 yaitu tahap ke-1: mengidentifikasi topik, tahap ke-2: merencanakan tugas, tahap ke-3: melakukan investigasi, tahap ke-4: menyiapkan laporan akhir, tahap ke-5: mempresentasikan, tahap ke-6: evaluasi.

Kegiatan yang terakhir adalah kegiatan penutup guru memberi penguatan materi, guru bersama siswa membuat kesimpulan menyimpulkan materi pembelajaran.

Penelitian siklus I pertemuan II dilaksanakan hari kamis 9 Januari 2020 pukul $09.00-12.30$ WIB dengan alokasi waktu 4 x 35 menit materinya kewajiban di sekolah dan pengaruh negatif interaksi manusia dengan lingkungan. Pada tahap ini memiliki tiga tahapan yaitu Kegiatan awal, kegiatan inti dan kegiatan penutup.

Kegiatan awal merupakan kegiatan guru mengkondisikan, berdo'a bersama dan mengecek kehadiran siswa, guru bersama siswa menyanyikan lagu nasional seperti "Satu Nusa Satu Bangsa".guru melakukan apersepsi sebelum masuk ke pembelajaran. Masuk selanjutnya yakni kegiatan inti dalam kegiatan inti guru menerapkan langkah-langkah model Group Investigation, adapun tahapanya ada 6 yaitu tahap ke-1: mengidentifikasi topik, tahap ke-2: menrencanakan tugas, tahap ke-3: melakukan investigasi, tahap ke-4: menyiapkan laporan akhir, tahap ke-5: mempresentasikan, tahap ke-6: evaluasi.

Kegiatan yang terakhir adalah kegiatan penutup guru memberi penguatan materi, guru bersama siswa membuat kesimpulan menyimpulkan materi pembelajaran.

\section{c. Observasi / Pengamatan}

Tahap pengamatan dilakakukan selama proses pemebelajaran berlangsung. Peneliti dibantu oleh teman sejawat dan guru kelas V SD 5 Bae, dalam melaksankan kegiatan tahap pengamatan. Pada kegiatan ini meliputi, pengamatan terhadap hasil belajar siswa dalam proses pembelajaran muatan PPkn materi hak dan kewajiban di sekolah dan muatan IPS materi interaksi manusia dengan lingkungan alam dan pengaruh negatif interaksi manusia dengan dengan model Group Investigation berbantuan media Puzzle.Pada kegiatan ini dilakukan oleh oleh teman sejawat yaitu Laili Rasyidah.

Hasil belajar siswa pada siklus I dari tes evaluasi dengan jumlah 10 soal (lima soal PPKn dan lima soal IPS). Tes evaluasi dilakasanakan pada hari kamis 9 Januari 2020. Berdasarkan hasil tes evaluasi siklus I memperoleh rata-rata nilai klasikal 71 dengan keterangan siswa yang tuntas 10 siswa persentase $48 \%$ dan belum tuntas 11 siswa dengan persentase 52\%. Pada siklus I memperoleh nilai teringgi 87 dan nilai terendah 40. Berdasarkan data penelitian maka hasil belajar siswa pada siklus I muatan PPKn dan IPS belum mencapai indikator keberhasilan. Indikator keberhasilan dalam penelitian ini yakni sebanyak $75 \%$. Untuk lebih jelasnya hasil belajar siklus I dapat dilihat pada tabel tabel 1 dibawah ini. 
Tabel 1. Data Hasil Belajar siswa kelas V SD 5 Bae pada siklus

\begin{tabular}{|c|c|c|c|}
\hline \multicolumn{4}{|c|}{$I$} \\
\hline No & $\begin{array}{l}\text { Nama } \\
\text { Siswa }\end{array}$ & $\begin{array}{c}\text { Nilai } \\
\text { Siklus I }\end{array}$ & Kriteria \\
\hline 1. & $\mathrm{BDF}$ & 83 & Tuntas \\
\hline 2. & BA & 53 & $\begin{array}{l}\text { Belum } \\
\text { Tuntas }\end{array}$ \\
\hline 3. & DL & 63 & $\begin{array}{l}\text { Belum } \\
\text { Tuntas }\end{array}$ \\
\hline 4. & FL & 57 & $\begin{array}{l}\text { Belum } \\
\text { Tuntas }\end{array}$ \\
\hline 5. & HSS & 87 & Tuntas \\
\hline 6. & IA & 80 & Tuntas \\
\hline 7. & IPP & 70 & $\begin{array}{l}\text { Belum } \\
\text { Tuntas }\end{array}$ \\
\hline 8. & KDS & 63 & $\begin{array}{l}\text { Belum } \\
\text { Tuntas }\end{array}$ \\
\hline 9. & MSD & 57 & $\begin{array}{l}\text { Belum } \\
\text { Tuntas }\end{array}$ \\
\hline 10. & MFI & 80 & Tuntas \\
\hline 11. & MYDP & 70 & $\begin{array}{l}\text { Belum } \\
\text { Tuntas }\end{array}$ \\
\hline 12. & MYMP & 83 & Tuntas \\
\hline 13. & NO & 78 & Tuntas \\
\hline 14. & RAR & 67 & $\begin{array}{l}\text { Belum } \\
\text { Tuntas }\end{array}$ \\
\hline 15. & TYNI & 80 & Tuntas \\
\hline 16. & WA & 82 & Tuntas \\
\hline 17. & ZYD & 73 & $\begin{array}{l}\text { Belum } \\
\text { Tuntas }\end{array}$ \\
\hline 18. & AM & 67 & $\begin{array}{l}\text { Belum } \\
\text { Tuntas }\end{array}$ \\
\hline 19. & APM & 87 & Tuntas \\
\hline 20. & ZMU & 76 & Tuntas \\
\hline 21. & MAJL & 40 & $\begin{array}{l}\text { Belum } \\
\text { Tuntas }\end{array}$ \\
\hline $\begin{array}{l}\text { Jum } \\
\text { Yar }\end{array}$ & $\begin{array}{l}\text { lah Siswa } \\
\text { g Tuntas }\end{array}$ & 11( & $2 \%)$ \\
\hline $\begin{array}{l}\text { Jum } \\
\text { Yar }\end{array}$ & $\begin{array}{l}\text { lah Siswa } \\
\text { g Belum } \\
\text { Tuntas }\end{array}$ & 10( & $8 \%)$ \\
\hline
\end{tabular}

Dari data di atas dapat disimpulkan bahwa hasil belajar siswa kelas V SD 5 Bae menunjukan bahwa 11 siswa yang tuntas dengan persentase
$52 \%$ dan 10 siswa yang tidak tuntas dengan persentase $48 \%$. Sehingga dapat digambarkan dengan diagram 1.

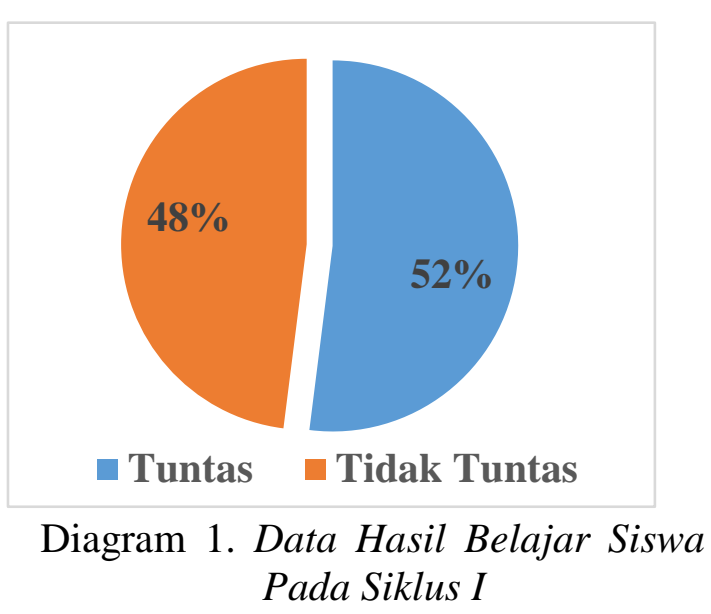

Berdasarkan penelitian yang dilakukan di kelas V SD 5 Bae dengan menggunakan kurikulum 2013, siswa dikatakan tuntas belajar secara individu apabila skor yang diperoleh minimal atau $\geq 75$. Dari data yang disajikan pada tabel 1 dan diagram 1 terdapat 11 siswa yang tuntas dengan persentase 52\% dan 10 siswa yang tidak tuntas dengan persentase $48 \%$. Dengan demikian penelitian dikatakan berhasil apabila mencapai ketuntasan belajar $\geq 75$.

\section{d. Refleksi}

dilakukan peneliti adalah mengevaluasi kegiatan pelaksanaan tindakan pada siklus I dari data setelah pelaksanaan tindakan tersebut bisa dilihat dari data-data yang terkumpul. Peneliti mengumpulkan dan menganalisis data yang diperoleh dari siklus I untuk ditindak lanjuti sebagai perbaikan proses pembelajaran dalam pelaksanaan pembelajaran pada siklus II. 


\section{Siklus II}

\section{a. Perencanaan}

Perencaan yaitu kegiatan yang dimulai dengan merencanakan ide peneliti yang merupakan hasil tindak lanjut dari observasi dikelas yang bertujuan untuk menemukan faktorfaktor penghamabat yang menyebabkan hasil pemebelajaran yang masih rendah. Pada permasalahan yang muncul, peneliti menggunakkan model Group Investigation berbantuan media puzzle untuk meningkatkan hasil belajar siswa. Pada tahap perencanaan pada siklus II diperoleh dari hasil refleksi terhadap siklus I. Tahap perencaan siklus II hal yang dilakukan oleh peneliti, sebelum peneliti melakukan penelitian tindakan kelas adapun kegiatan yang dilakukaan dalam tahap perencanaan pada siklus I antara lain: Membuat silabus, Membuat Rencana Pelaksanaan Pembelajaran (RPP), Membuat Lembar Kerja Siswa (LKS), Menyiapkan media, Membuat soal evaluasi untuk siklus I, Menentukan instrumen, Membuat pedoman observasi mengenai hasil belajar siswa, peneliti merencanakan pembentukan kelompok heterogen.

\section{b. Pelaksanaan}

Tahap pelaksanaan tindakan siklus II peneliti melaksanakan penelitian dan sekaligus menjadi guru pada siklus II pertemuan I dan Pertemuan II dikelas V SD 5 Bae, pada pelaksanaan penelitian, peneliti menggunakan pedoman RPP yang sudah dibuat sesuai dengan langkah model Group Investgation berbantuan media Puzzle. Tahap kedua yakni pelaksanaan, dalam penelitian dilaksanakan dengangan menerapkan model Group Investigation berbantuan media Puzzle untuk meningkatkan hasil belajar siswa pada tema 6 di SD 5 Bae. Pada pelaksanaan tindakan kelas pada siklus II pertemuan I yaitu pada hari Selasa, 14 Januari 2020, dan siklusI II pertemuan II pada hari Kamis, 16 Januari 2020.

Penelitian siklus II pertemuan I dilaksanakan hari selasa 14 Januari 2020 pukul 09.00 - 12.30 WIB dengan alokasi waktu 4 x 35 menit materinya kewajiban warga negara Indonesia dan interaksi manusia dengan lingkungan ekonomi .Pada tahap ini memiliki tiga tahapan yaitu kegiatan awal, kegiatan inti dan kegiatan penutup.

Kegiatan awal merupakan kegiatan guru mengkondisikan, berdo'a bersama dan mengecek kehadiran siswa, guru bersama siswa menyanyikan lagu nasional seperti "Dari Sabang sampai Merauke ". Guru melakukan apersepsi sebelum masuk ke pembelajaran. Masuk selanjutnya yakni kegiatan inti dalam kegiatan inti guru menerapkan langkah-langkah model Group Investigation, adapun tahapanya ada 6 yaitu tahap ke-1: mengidentifikasi topik, tahap ke-2: merencanakan tugas, tahap ke-3: melakukan investigasi, tahap ke-4: menyiapkan laporan akhir, tahap ke-5: mempresentasikan, tahap ke-6: evaluasi.

Kegiatan yang terakhir adalah kegiatan penutup guru memberi penguatan materi, guru bersama siswa membuat kesimpulan menyimpulkan materi pembelajaran. Penelitian siklus II pertemuan II dilaksanakan hari kamis 16 Januari 2020 pukul 09.00 12.30 WIB dengan alokasi waktu $4 \mathrm{x}$ 35 menit materinya Hak dan Kewajiban Sesuai dengan Perannya dan Interaksi manusia dengan lingkungan ekonomi. Pada tahap ini memiliki tiga tahapan yaitu Kegiatan 
awal, kegiatan inti dan kegiatan penutup.

Kegiatan awal merupakan kegiatan guru mengkondisikan, berdo'a bersama dan mengecek kehadiran siswa, guru bersama siswa menyanyikan lagu nasional seperti "Satu Nusa Satu Bangsa". Guru melakukan apersepsi sebelum masuk ke pembelajaran. Masuk selanjutnya yakni kegiatan inti dalam kegiatan inti guru menerapkan langkah-langkah model Group Investigation, adapun tahapanya ada 6 yaitu tahap ke-1: mengidentifikasi topik, tahap ke-2: merencanakan tugas, tahap ke-3: melakukan investigasi, tahap ke-4: menyiapkan laporan akhir, tahap ke-5: mempresentasikan, tahap ke-6: evaluasi.

Kegiatan yang terakhir adalah kegiatan penutup guru memberi penguatan materi, guru bersama siswa membuat kesimpulan menyimpulkan materi pembelajaran.

\section{c. Observasi / Pengamatan}

Tahap pengamatan dilakakukan selama proses pemebelajaran berlangsung. Peneliti dibantu oleh teman sejawat dan guru kelas V SD 5 Bae, dalam melaksankan kegiatan tahap pengamatan. Pada kegiatan ini meliputi, pengamatan terhadap hasil belajar siswa dalam proses pembelajaran muatan PPkn materi kewajiban warga negara indonesia , hak dan kewajiban sesuai dengan perannya dan muatan IPS materi Interaksi manusia dengan lingkungan ekonomi, Interaksi manusia dengan lingkungan ekonomi dengan model Group Investigation berbantuan media Puzzle.

Pada kegiatan ini dilakukan oleh teman sejawat yaitu Laili Rasyidah dan Nurul Hidayah.
Hasil belajar siswa pada siklus II dari tes evaluasi dengan jumlah 10 soal (lima soal PPKn dan lima soal IPS). Tes evaluasi dilakasanakan pada hari kamis 16 januari 2020. Berdasarkan hasil tes evaluasi siklus II memperoleh rata-rata nilai klasikal 75 dengan keterangan siswa yang tuntas 16 siswa persentase $76 \%$ dan belum tuntas 5 siswa dengan persentase $24 \%$. Pada siklus II memperoleh nilai tertinggi 93 dan nilai terendah 50 . Berdasarkan data penelitian maka hasil belajar siswa pada siklus II muatan PPKn dan IPS sudah mencapai indikator keberhasilan. Indikator keberhasilan dalam penelitian ini yakni sebanyak $75 \%$. Untuk lebih jelasnya persentase hasil belajar siklus dapat dilihat pada tabel Tabel 2 dibawah ini.

Tabel 2. Data Hasil Belajar siswa kelas V SD 5 Bae pada siklus I

\begin{tabular}{cccc}
\hline No & $\begin{array}{c}\text { Nama } \\
\text { Siswa }\end{array}$ & $\begin{array}{c}\text { Nilai } \\
\text { Siklus I }\end{array}$ & Kriteria \\
\hline 1. & BDF & $\mathbf{8 3}$ & Tuntas \\
2. & BA & $\mathbf{8 6}$ & Tuntas \\
3. & DL & $\mathbf{8 0}$ & Tuntas \\
4. & FL & $\mathbf{9 0}$ & Belum \\
& & & Tuntas \\
5. & HSS & $\mathbf{8 3}$ & Tuntas \\
6. & IA & $\mathbf{7 0}$ & Tuntas \\
7. & IPP & $\mathbf{7 0}$ & Belum \\
& & & Tuntas \\
8. & KDS & $\mathbf{7 3}$ & Belum \\
& & & Tuntas \\
9. & MSD & $\mathbf{9 0}$ & Tuntas \\
10. & MFI & $\mathbf{7 6}$ & Tuntas \\
11. & MYDP & $\mathbf{7 3}$ & Belum \\
& & & Tuntas \\
12. & MYMP & $\mathbf{8 3}$ & Tuntas \\
13. & NO & $\mathbf{7 8}$ & Tuntas \\
14. & RAR & $\mathbf{8 6}$ & Tuntas \\
15. & TYNI & $\mathbf{8 3}$ & Tuntas \\
16. & WA & $\mathbf{8 0}$ & Tuntas \\
17. & ZYD & $\mathbf{8 6}$ & Tuntas \\
& & &
\end{tabular}




\begin{tabular}{|c|c|c|}
\hline $\mathrm{AM}$ & 86 & Tuntas \\
\hline APM & 93 & Tuntas \\
\hline ZMU & 86 & Tuntas \\
\hline MAJL & 70 & $\begin{array}{l}\text { Belum } \\
\text { Tuntas }\end{array}$ \\
\hline $\begin{array}{c}\text { Jumlah Siswa } \\
\text { Yang Tuntas }\end{array}$ & \multicolumn{2}{|c|}{$16(76 \%)$} \\
\hline $\begin{array}{c}\text { Jumlah Siswa } \\
\text { Yang Belum } \\
\text { Tuntas }\end{array}$ & \multicolumn{2}{|c|}{$5(24 \%)$} \\
\hline
\end{tabular}

Dari data diatas dapat disimpulkan bahwa hasil belajar siswa kelas V SD 5 Bae menunjukan 16 siswa yang tuntas dengan persentase $76 \%$ dan 5siswa yang tidak tuntas dengan persentase 24\%. Sehingga dapat digambarkan dengan Diagram 2.

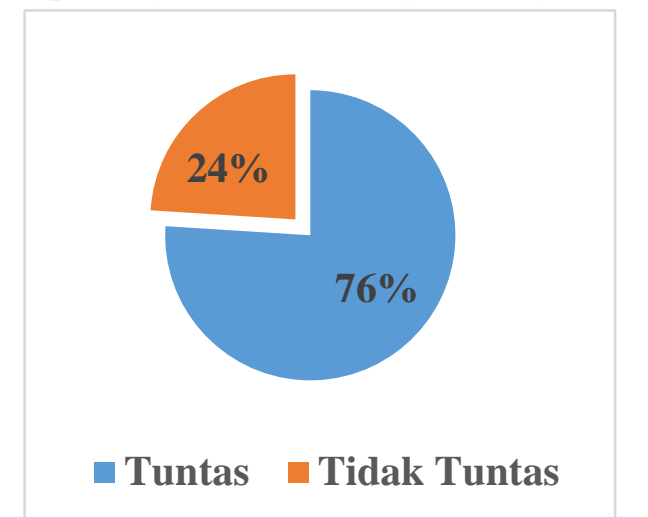

Diagram 2. Data Hasil Belajar Siswa
Pada Siklsu II

Berdasarkan penelitian yang dilakukan di kelas V SD 5 Bae dengan menggunakan kurikulum 2013, siswa dikatakan tuntas belajar secara individu apabila skor yang diperoleh minimal atau $\geq 75$. Dari data yang disajikan pada tabel 1 dan diagram 2 terdapat 16 siswa yang tuntas dengan persentase $76 \%$ dan 5siswa yang tidak tuntas dengan persentase 24\%. Dengan demikian penelitian dikatakan berhasil apabila mencapai ketuntasan belajar $\geq 75$.

\section{d. Refleksi}

dilakukan peneliti adalah mengevaluasi kegiatan pelaksanaan tindakan pada siklus II dari data setelah pelaksanaan tindakan tersebut bisa dilihat dari data-data yang terkumpul.

Berdasarkan data peneliti diperoleh Berdasarkan hasil tes evaluasi siklus II memperoleh rata-rata nilai klasikal 75 dengan keterangan siswa yang tuntas 16 siswa persentase $76 \%$ dan belum tuntas 5 siswa dengan persentase $24 \%$. Pada siklus II memperoleh nilai tertinggi 93 dan nilai terendah 50. Berdasarkan data penelitian maka hasil belajar siswa pada siklus II muatan PPKn dan IPS sudah mencapai indikator keberhasilan. Indikator keberhasilan dalam penelitian ini yakni sebanyak 75\%. Hasil penelitian tindakan kelas yang telah dilakukan perlu dianalisa lebih lanjut sehingga menjadi jelas dan bermakna. Oleh karena pada bagian berikut disajikan analisa terhadap hasil belajar.

Hasil Belajar menurut Snelbeker dalam Rusmono ( 2012: 8) menyatakan bahwa hasil belajar merupakan perubahan atau kemampuan baru yang diperoleh siswa setelah melakukan perbuatan belajar, karena belajar pada dasarnya adalah perilaku sesorang berubah sebagai akibat dari pengalaman. Slameto (2013) Hasil belajar adalah sebuah kalimat yang terdiri dari dua kata yaitu hasil dan belajar. Penilaian Hasil Belajar pada riset menggambil landasan dari Kosasih (2014: 12-27) menyatakan ada 3 taksonomi tujuan pengajaran dalam (1) ranah afektif atau sikap terdapat lima jenjang proses berfikir, yakni: Menerima atau memerhatikan (reveiring atau attending), Merespon atau menanggapi (responding), Menilai atau menghargai (valuing), 
Mengorganisasikan atau mengelola (organization), Berkarakter (characterization), (2) ranah kognitif terdapat enam jenjang yakni: (remembering (mengingat), understanding (memahami), applying (menerapkan), analyzing (menganalis, mengurai), evaluating (menilai), dan creating (mencipta), dan(3) ranah psikomotorik ada tujuh kategori dalam ranah psikomotorik mulai dari tingkat yang sederhana hingga tingkat rumit, yakni sebagai berikut: persepsi, kesiapan, reaksi yang diarahkan, reaksi natural, reaksi yang di komlpleks, adaptasi, kreativitas.

Hasil riset siklus I menunjukkan bahwa terdapat kekurangan pada saat evaluasi siklus I hasil belajar siswa masih rendah karena pada saat pembelajaran masih ada siswa yang tidak memperhatikan dan berbicara dengan teman sebangku, Masih ada siswa yang malu dan belum percaya diri untuk mengemukakan pendapatnya, Siswa masih jarang mengajukan pertanyaan terkait materi yang diajarakan dan jarang menanggapi jika ada kelompok yang maju, Guru belum sepenuhnya mampu menguasi kelas disaat diskusi kelompok berlangsung. Slameto (2013) Penilaian hasil belajar peserta didik tidak hanya diukur dari tingkat penguasaan ilmu pengetahuan mereka, tetapi dinilai dari dari sikap dan keterampilan peserta didik.

Kekurangan pada siklus I telah diperbaiki di siklus II dengan memaksimalkan pembelajaran dengan menggunakan model Group Investigation berbantuan media puzzle. Kondisi setelah diterapkannya model sehingga membuat keadaan kelas menjadi kondusif, siswa lebih cederung aktif bertanya, dan mendengarkan saat pembelajaran, Guru memberikan motivasi kepada siswa dan membantu siswa dalam merangkai kata-kata yang akan diungkapkan, Untuk mengatasi hal tesebut seharusnya guru memberikan reward kepada kelompok yang tertib.

Berdasarkan penjelasan tersebut dapat ditarik kesimpulan bahwa hipotesis tindakan yang diajukan telah terbukti dan indikator keberhasilan telah berhasil tercapai dengan memperoleh persentase rata-rata siklus II sebesar $76 \%$. Hal terebut sejalan dengan penelitian Muhajir dan Rukman (2018) siklus I yaitu 29,41\% meningkat menjadi $76,47 \%$ pada siklus II, penelitian ini sejalan dengan penelitian Reza (2019) hasil analisa data menunjukkan bahwa hasil belajar siswa mencapai ketuntasan klasikal sebesar 83,87 \% (ketuntasan terpenuhi).

\section{KESIMPULAN}

Berdasarkan hasil penelitian tindakan kelas atau PTK yang di lakukan pada kelas V SD 5Bae dapat disimpulkan bahwa ada peningkatan hasil belajar siswa melalui penerapan model Gruop Investigation berbantuan media Puzzle. Peningkatan tersebut dapat dilihat sebabagi berikut.

Meningkatkan hasil belajar dalam pembelajaran tema 6 muatan PPKn dan IPS penerapan model Group Investigation berbantuan media Puzzle pada siklus I memperoleh 11 siswa tuntas dengan persentase 52\% dan siswa yang tidak tuntas 10 siswa dengan persentase $48 \%$ dengan ratarata nilai klasikal 71 , meningkat pada siklus II memperoleh 16 siswa tuntas dengan persentase $76 \%$ dan siswa yang tidak tuntas 5 siswa dengan persentase $24 \%$ dengan rata-rata nilai klasikal 75 . 


\begin{abstract}
Hasil belajar dalam pembelajaran tema 6 muatan PPKn dan IPS penerapan model Group Investigation berbantuan media Puzzle pada siklus I sebesar 52\% dengan kriteria cukup memperoleh rata-rata siswa yang tuntas 11 siswa, mengalami peningkatan pada siklus II sebesar $76 \%$ dengan kriteria baik memperoleh ratarata siswa yang tuntas 16 siswa.
\end{abstract}

\section{DAFTAR PUSTAKA}

Arikunto, Suharsimi . 2011. Penelitian Tindakan untuk Kepala Sekolah \& Pengawas. Yogyakarta: Aditya Media.

Aryani, Bekti. 2019. Meningkatkan Antusiasme dan Hasil Belajar Siswa dengan Model Picture and Picture Berbantuan Media Puzzle pada Muatan Matematika, Bahasa Indonesia, dan PPKn Kelas 1 SD. Jartika. 1 (2), 294.

Erlisnawati. Hendri Marhadi. 2014. Penerapan Model Pembelajaran Kooperatif Tipe Group Investigation Untuk Meningkatkan Hasil Belajar IPS Siswa Kelas IV SD Negeri 56 Pekanbaru. Jurnal Primari PGSD Universitas Riau. 3 (1), 13.

Febriyani, Herlina dan Raudhah Awal. 2015. Pengaruh Strategi Pembelajaran The Power Of Two Berbantuan Crossword Puzzle Terhadap Hasil Belajar Siswa Pada Materi Gerak Pada Tumbuhan Di Kelas VIII SMP Negeri 1 Minas. Jurnal Lectura.

Kosasih. 2014. Strategi Belajar dan pembelajaran. Bandung: Yrama Widya.
Kunandar. 2015. Penilaian Autentik (Penilaian Hasil Belajar Peserta Didik Berdasarkan Kurikulum 2013). Jakarta: PT Rajagrafindo Persada.

Muhajir. Andi Auliah Rukman. 2018. Peningkatan Hasil Belajar PKn melalui Pembelajaran Kooperatif Tipe Group Investigation pada Murid Kelas IV SD Inpres Boronguntia Kecamatan Bajeng Kabupaten Gowa. Jurnal Etika Demokrasi PPKn. 3 (1), 29.

Rumakhit, Nur. 2017. Pengembangan Media Puzzle Untuk Pembelajaran Materi Mengidentifikasi Beberapa Jenis Simbiosis Dan Rantai Makanan Kelas IV Sekolah Dasar Tahun 2016/2017. Simki-Pedagogis. 1 (2), 6-8.

Rusmono. 2012. Strategi Pembelajaran dan Problem Based Learning itu perlu. Bogor: Ghalia Indonesia.

Rusmono. 2012. Strategi Pembelajaran dan Problem Based Learning itu perlu. Bogor : Ghalia Indonesia.

Santrianawati. 2018. Media dan Sumber Belajar. Yogyakarta: CV Budi utama.

Sari, Ermina dan Zamifa Hautruviana. 2013. Pengaruh Model Pembelajaran Kooperatif Tipegroup Investigation Terhadap Hasil Belajar Siswa Pada Materi Sistem Pernapasan Di Kelas XI IPASMA Nurul Falah Pekanbaru. Jurnal Lectura.

Shoimin, Aris. 2014. 68 Model Pembelajaran Inovatif dalam Kurikulum 2013. Yogyakarta: Ar-Ruzz Media. 
Slameto. 2013. Belajar dan Faktorfaktor yang Mempengaruhinya. Jakarta: PT Rineka Cipta.

Syehma Bahtiar, Reza. 2019. Metode Probing-Prompting dalam Meningkatkan Kemampuan Melengkapi Puisi bagi Siswa Sekolah Dasar. Jurnal Lectura Vol.11 No. 1.

Tanireja, turikan. et.al . 2011. ModelModel Pembelajaran Inovatif. Bandung: Alfabeta.

Zuhairah, Nurul. 2015. Pendidikan Moral \& Budi Pekerti dalam Perspketif Perubahan. Jakarta: PT Bumi Aksara. 